\title{
SPAIS
}

\section{Critical Terrorism Studies: An Activist Scholar Perspective}

\author{
Eric Herring \\ University of Bristol \\ (C) Eric Herring
}

School of Sociology, Politics, and International Studies, University of Bristol Working Paper No. 03-08

Dr. Eric Herring is a Reader in International Politics at the University of Bristol. His most recent book is Iraq in Fragments: The Occupation and its Legacy, published in 2006 by Cornell University Press and Hurst: this was co-authored with Dr. Glen Rangwala (Cambridge) as part of a project funded by the Economic and Social Research Council. He was specialist adviser to the Select Committee on Economic Affairs of the House of Lords for its inquiry into economic sanctions in 2006-07. He has published articles in journals such as Review of International Studies, Millennium, The International Journal of Human Rights, Third World Quarterly and The Journal of Strategic Studies.

This paper is forthcoming in Critical Studies on Terrorism, 1 (2), 2008. 


\title{
Critical Terrorism Studies: An Activist Scholar Perspective
}

\begin{abstract}
:
There is a pressing need for critical terrorism studies. Mainstream terrorism studies obscures the class function of terrorism, values the worthy victims of official enemies over the unworthy victims of official allies, keeps Northern state terrorism off the agenda and deploys the concept of terrorism in a way that deleitimises opposition to the power of the global North while legitimising the global North's own political violence. Critical terrorism studies should break with mainstream terrorism studies on all of these fronts. It should address how terrorism has evolved as an instrument of the power and privilege of the global North. It should treat the victims of terrorism equally on the basis of their common humanity, which means the terrorism of the global North or global South should not be treated as the only terrorism that matters. And it should use the label terrorism to hold up a mirror to those who accuse others of terrorist acts but who engage in, sponsor or are complicit in such acts themselves. Finally, it should situate its challenge to terrorism within a challenge to the use of political violence in general.
\end{abstract}




\title{
Critical Terrorism Studies: An Activist Scholar Perspective
}

\author{
Eric Herring
}

Critical terrorism studies is a welcome development, and in this paper I aim to offer analysis that may assist it in making a contribution to what those within critical security studies would call emancipatory practice in world politics. By emancipatory practice I refer to actions motivated by the desire to assist others or prevent harm to them because they are fellow human beings (as opposed to members of one's own nation or other supposed fraction of humanity) and aimed at ensuring they are free to live full and positive lives on equal terms to our privileged own (as opposed to some lesser standard due to them being members of a different community). Of course, the notion of emancipation is far from being unproblematic, and reflection on its silences and potential pitfalls are a necessary concomitant of advocating it. Bearing that in mind, critical terrorism studies could contribute greatly to emancipatory practice in world politics by addressing an agenda of related issues that mainstream terrorism studies has tended to avoid and by making the case for the incorporation of that agenda into terrorism studies per se rather locating it within a separate critical terrorism studies sub-field.

The agenda I propose is animated by an activist scholar perspective, that is, one in which scholarship is directed towards supporting non-violent action against oppression: this resonates with the emancipatory commitment of critical terrorism studies and connects it explicitly to practice (Herring 1996, Naspir n.d., Lawson 2008). It has the further advantage of making it more likely that the commitments of critical terrorism studies to a universalist notion of emancipation and alternatives to physical violence as an instrument of politics will be tested by self-reflexive dialogue with actually existing social movements and indeed states that are communitarian and inclined towards seeing physical violence as often effective and legitimate (Gunning 2007). It should be underlined that activist scholarship does not mean that scholarly standards should ever be sacrificed in any way to activism: the former should always take precedence otherwise what is being written ceases to be scholarship. An activist scholar perspective also involves scepticism towards the claims that either what one might call an insider activist commitment to policy relevance or a more traditional 
claim to producing knowledge for its own sake are necessarily less likely to result in biased or tendentious analysis. The normative and political are unavoidable in deciding what to study and what not to study, how to study it and to whom the results of that study are directed. Hence scholarship is enhanced by realising that this is the case (a necessary prior stage often missed or denied by traditionalists) and accounting explicitly for those choices.

The specific agenda proposed in this article for incorporation into terrorism studies, critical and mainstream, has five inter-related components. First, class should be brought back in to the study of terrorism within a broadly historical materialist framework that is sensitive to the discursive as well as the material and to the mutual constitution of both. I say 'back' in because an attempt was made in the 1970s and 1980 s but the mainstream of terrorism studies remained essentially unchanged. Constructivism, discourse analysis and critical theory would have more to offer with re-connection to ideas of class, capitalism, imperialism and neoliberal globalisation. Second, critical terrorism studies should operate on the basis of the equal rights of all and not worthy and unworthy victims. Third, while non-state terrorism should remain on the agenda, much more attention than hitherto should be given to state terrorism, including Northern state terrorism. There is voluminous evidence of Northern use and sponsorship of and complicity in what would be termed terrorism using a mainstream terrorism studies definition such as actual or threatened use of violence against civilians with the aim of creating fear among a wider civilian population as a means of achieving political goals. In contrast, mainstream terrorism studies mostly assumes benign if occasionally misguided liberal states acting against non-state terrorists who are sometimes backed by non-liberal states. Fourth, taboo cases should be addressed. For example, Israel actions should be put on the agenda of terrorism studies: this can be done without losing sight of Palestinian ones and would be an fundamental improvement of the current exclusive focus in terrorism studies on Palestinian actions. Israel uses, sponsors and is complicit in violence that might be categorised as terrorism and yet this is a taboo topic in terrorism studies, and success in opening up discussion in this case could assist in opening up others. Furthermore, it would require critical terrorism studies to engage in the self-reflexive dialogue mentioned earlier because its emphasis on universalism and non-violence would be challenged by the fact that there is much public support among Israelis and Palestinians for acts that could be defined as terrorism. Fifth, any engagement with the term 'terrorism' should 
be part of a wider project of moving beyond its use. This might seem to contradict arguing that that the term can be applied to many of the acts of states including Northern states, but actually both are part of the same deeper project of challenging the use of violence, especially against civilians, for political purposes. Where the strategy is one of delegitimation of such acts, terrorism is a powerful label to use. Another strategy is one of holding up a mirror, showing acts that condemned by one side as terrorism are that acts it too has carried out. In both cases, the use of the term is contingent. It is often the case that the most useful thing to do in promoting emancipatory practice is to not use the label, and in the final section of the article I consider when this might be the case.

\section{Bring class back in - historical materialism and the neglected referent in security studies}

Mainstream terrorism studies is located within the realist and liberal traditions of world politics. Any version of classical or neo-realism is clearly incompatible with the emancipatory and activist commitments of critical terrorism studies. Liberalism has much to offer in terms of universalist ideas of human rights, the importance of norms and law as restraints on power and the pursuit of cooperation. However, liberalism has repeatedly demonstrated that it has a repressive, illiberal and imperial side, not as a mistake or as something forced upon it to survive in an illiberal world, but as inherent to the liberal project (for this critique see recently, among many others, Duffield 2007). Liberalism's positive normative side can only be salvaged - and taken more seriously than liberalism itself takes it - by framing it within a theorisation of world politics which is much more attuned to the existence and historical specificity of inequality, hierarchy and exploitation (Overbeek 2004). Discourse analysis and constructivism cannot supply this as they are not theories of world politics, only methods of analysis, and can be applied within a range of theories of world politics. Post-structuralism is more concerned with challenging grounds than providing them and while this is valuable, it also remains a limited exercise.

For critical terrorism studies to gain more analytical and political purchase, it needs to ground itself in some forms of broader theorising about world politics, and ones which are notably distinct from those that underpin mainstream terrorism studies. The very name critical terrorism studies suggests that it is already grounded in critical security studies and beyond that critical theory. The eclectic approach sees 
critical security studies as united by a political and theoretical orientation towards non-state-centric emancipatory politics and emphasises constructivism and to a much lesser extent post-structuralism (Krause, Williams 1997, Krause 1998, Fierke 2007). In contrast, the focused approach sees critical security studies as having a central commitment to Frankfurt School critical theory (Wyn Jones 1999). In between the two Ken Booth advocates 'critical global theorising' which includes Frankfurt School critical theory, Gramscianism, Marxism and cosmopolitan critical international relations theory, with some versions of feminism and constructivism falling within these categories (Booth 2005a, 2007, 2008).

In the development of critical security studies thus far, never mind mainstream security studies, historical materialist (Marxist, neo-Marxist and fusions of these with post-Marxist as opposed to exclusively post-Marxist) elements have been present to a minimal degree. For example, Karin Fierke's Critical Approaches to International Security (2007) makes only passing mention to Marx and none to class, capitalism or neoliberalism (despite it being the currently dominant ideology, form and project of capitalism). In David Mutimer's overview of critical security studies in the textbook edited by Alan Collins (one of the standard textbooks on security studies), Marxism is mentioned only once in terms of Booth's endorsement of it as part of critical security studies, and with critical theory framed as post-Marxist (2007, pp. 62, 63). While critical theory has its origins in Marxism, as Mutimer hints it has become somewhat distanced from Marxist and neo-Marxist scholarship, even though that scholarship continues to flourish. Richard Wyn Jones's (1999) attempt to ground critical security studies in Frankfurt school critical theory involved relying mainly on Ulrich Beck's post-Marxism. One chapter in Booth's edited volume Critical Security Studies and World Politics (2005b) has a few brief discussions of Marxism and capitalism and a slightly more sustained discussion of neoliberalism but nothing on class. The lack of interest in historical materialism is a major weakness and imbalance within critical security studies as it has developed thus far. There has been an overwhelming emphasis on the ideational, discourse analysis, constructivism and post-structuralism, and this is a crucial limitation on its ability to theorise world politics in a systematic and politically relevant way. Meanwhile, scholars working with historical materialist perspectives are generating far-reaching and influential analyses which locate the discursive within the context of hierarchically structured relations at multiple levels globally (e.g. Harvey 2000, 2005, Jessop 2002, 2003, 2007). Such analyses have been 
central to the enormously successful development of critical geography, critical sociology and critical education studies, all politically engaged fields intertwined with actually existing current social movements (e.g. ICCG n.d., Antipode n.d.). As Booth, in defining it as being within the scope of critical security studies, states: 'The Marxian tradition offers a deep mine of ideas that are especially useful for thinking about ideology, class, and structural power' (2005a, p. 261). As he also states, 'class $\ldots$ is a much-ignored referent, despite massive life-threatening and life-determining insecurity being the direct result of poverty' (2007, p. 197). Historical materialism, including its Gramscian and historical sociology variants, is flourishing within IR (for a survey see Hobden, Wyn Jones 2005) and is a major resource for critical terrorism studies.

Those who 'do' historical materialist analysis generally do not 'do' security studies, for political reasons in that they see it overwhelmingly as a field which serves mainly as an instrument of class domination and for intellectual reasons in that the concept of security is seen as a relatively unsatisfying one for theorising about world politics. The problem with this approach is that students new to security studies will effectively, even if unintentionally and despite Booth's assertion to the contrary, be guided to the conclusion that they have little to learn from historical materialism and do not need to think about class and capitalism. Path dependency - roads more and less travelled - will operate in a powerful way. For example, the 'Approaches to Security' section of the first edition of the Collins Contemporary Security Studies textbook (2007) effectively sets out security studies as involving choices between a traditional state-centric realist-liberal framing, a discursive-constructivist critical framing or one focused thematically on peace studies, gender, securitisation or human security. Marxism is discussed briefly in the traditional approaches chapter which is structured around realism and liberalism.

The lessons for the emergent field of critical terrorism studies are clear. Bringing the state back into terrorism studies is valuable, but not enough - what is required is a class analysis of the state and terrorism, one that is historically specific to the changing dynamics of capitalist globalisation, and one which considers the ways that terrorism can be a tactic of all sides in class conflict, rather than just a tactic of a subordinate class. Such a perspective would distinguish it strongly from mainstream terrorism studies up to now. It would also provide it with a way of describing, explaining and challenging Northern state terrorism because it would frame it in terms 
of the extent to which it is functional for shoring up or challenging exploitative relations which favour capital over labour. The good news is that the work of scholars such as Doug Stokes (2005, 2006) and Ruth Blakeley (2007, in progress) is leading the way, building on the work of Edward Herman and Noam Chomsky, and ensuring that critical terrorism studies has a major strand which puts the discursive and ideological into the context of US-led capitalist globalisation and associated class relations.

Bringing class back in begs the question of what one means by class, of course. This is a huge question far beyond the scope of this article. What can be said here is that, while class has an important economic dimension, it is not reducible to economics with the non-economic separate and secondary. As Henk Overbeek (2004, p. 3) puts it:

Class is a broad and inclusive concept that refers to the situation of human beings in the social relations through which they produce and reproduce their existence, and by which they are in turn constituted as social beings. These social relations of (re-)production are hierarchical and exploitative. They are furthermore guaranteed by the state: in the era of the dominance of capitalist social relations, they are guaranteed by the capitalist state.

A whole host of related issues must be addressed, such as how many classes there are, how distinct they are, how movement occurs between them, the extent to which and ways in which classes are antagonistic, how particular social formations are stabilised through means such as class compromises compared with the threat or use of coercive means such as terrorism, the relationships between classes and elites (i.e. social and agentic concentrations of power of whatever kind), how classes are organised within and across states, how they can be united on some things and divided on others and how those divisions may be objective or perceptual. The class role that terrorism plays may be functional or dysfunctional and driven by complex interaction of fractions of classes and elites (subnational, national, transnational) and progressive or reactionary opposition. States may tolerate or promote progressive developments such as a move from dictatorship to liberal democracy. A class analysis would expect in general terms that this will occur only when ruling class power is not threatened or where it simply lacks sufficient power to prevent those developments. Consideration 
will also need to be given to understanding when and how forces such as nationalism, ethnicity, religion or sect can be the primary dynamic shaping resort or non-resort to terrorism. A guard must also be maintained against a tendency often associated with historical materialist perspectives of undervaluing liberal democracy and other often progressive aspects of liberalism.

Bringing class back in does not mean class reductionism: terrorism is not all about class - the point being made here is the rejection of the implicit assumption that class has nothing to do with terrorism, including Northern state terrorism, or only plays a role in class rebellion from below. By Northern states I mean industrial and post-industrial capitalist ones. They may be liberal democratic or authoritarian, although they are overwhelmingly in the former group. Hence it is not a geographical category, as such states can be located in the southern hemisphere (such as Australia). By Southern states I mean those with low levels of industrial and post-industrial capitalist development. The North is more or less a post-Cold War synonym for 'Western', though with the obvious qualification that there is no non-capitalist East with which it is struggling for the political, military and economic allegiance of a Third World. Instead, the United States is trying to balance its own interests with keeping the other Northern democratic states on board while engaging with the structural shift associated with China's increasingly global version of authoritarian Northern capitalism. The 'North' and the 'global North' are frequently used as synonyms (the latter being the trendy version): the problem with this approach is that the phrase 'global North' is useful to encapsulate the fact that within Northern states substantial elements of society are part of the global South, defined as those which are marginal to advanced capitalism, impoverished and policed or just ignored. Their poverty, hunger, ill health and shortened life spans can be witnessed across the world. Equally, within Southern states there are substantial elements of society which are part of the global North, defined as those which are deeply integrated into advanced capitalism, wealthy and on behalf of which the global South is policed, securitised and if necessary repressed. The people of the global North and global South correspond roughly to Mark Duffield's (2007) categories of insured and uninsured or surplus life (for an application to post-invasion Iraq, see Herring, forthcoming 2008). As such, it is above all a class rather than a geographical distinction or a distinction between types of state. Within this system, terrorism can be a means of capital accumulation by violent and intimidatory dispossession, opposition to it or part of a 
bid to take part in it. Nevertheless, the world is structured and stratified around multiple inequalities and critical terrorism studies needs to be attentive to what they are and how they relate to the use and non-use of terrorism. A particularly important inequality which critical terrorism studies ought to challenge is the operation of the categories of worthy and unworthy victims.

\section{Move beyond worthy and unworthy victims to the equal rights of all}

In Northern discourses on terrorism, the suffering of the victims of official enemies of the North (the worthy victims) is mourned and the suffering of the victims of the North and its allies (the unworthy victims) played down (Chomsky, Herman 1979). This approach should be rejected on the principle that all should be regarded, by virtue of their common humanity, as equal in terms of human rights. It follows that there should be no reversal of the current worthy-unworthy victims categories, with the victims of the North and its allies valued more highly than the victims of its opponents. Those on the political right (Horowitz 2006), and some such as Martin Shaw (2001) and Nick Cohen (2007) who are more liberal-left believe that that reversal is the norm on much of the left. The same concern and criteria should apply to all those who live in the shadow of state and non-state terrorism. However, there are four reasons why it is valid for scholars in the North to pay much more attention to the victims of the North and its allies. Firstly, it is necessary to fill the gap in analysis which some of those in mainstream terrorism studies accept does exist. The aim would be to equalise the level of concern. Secondly, this suffering is being inflicted by the governments of Northern scholars or state and non-state allies of those governments with their financial, military or political support and supposedly for their benefit. To the extent that our taxes and governments are involved, we are implicated, though this is tempered by limits on our ability to change that situation. Thirdly, it challenges directly the usual liberal, often armed, interventionist narrative about how a morally superior 'us' should act to impose order and civilisation on a morally inferior 'them'. The framing shifts from what we are entitled to do to 'them' to a framing of what 'we' should simply stop doing. The policy recommendation 'Just stop it' is simple and yet will seem outlandish and incomprehensible to the liberal interventionist mindset. Fourthly, Northern states claim to be acting according to a higher moral standard than their opponents and so it is entirely reasonable to compare their behaviour to this claim. 
Approached in this way, critical terrorism studies could work to focus much more attention on the human costs of the exercise of Northern power without reversing the worthy-unworthy victim hierarchy. During the Cold War, Chomsky and Herman $(1979$, pp. 37, 38) made a similar argument:

If the purpose of protests is self-aggrandizement, service to one's state, establishing credentials with one's compatriots or deity, or other self-serving motives, then it is clear how to proceed; join the chorus of protests organized by the government or the media with regard to the iniquity of the current enemies of the state. Such protest may be directed towards genuine abuses of human rights, but it is at the moral level of protest for pay. We understand this very well in the case of official enemies. Suppose some Russian intellectual condemns U.S. behavior in Chile or Vietnam. What he says may be quite true, but we do not admire his courage or moral integrity. Similar remarks apply here, and for the very same reasons. ... The emphasis should, in general, be close to home: on violations of human rights that have their roots in the policies of one's own states, or its client regimes, or domestic economic institutions ..., and, in general, on policies that protests may be able to influence.

What they propose as an emphasis is fine as a broad rule of thumb (which is how they characterise it). However, important qualifications to their general position should be set out. Recording and memorialisation - both fraught with complexities, naturally are valuable symbolic acts in themselves even if they have no direct practical effect in preventing others from falling victim to acts of terrorism. In addition, it may be that there are cases in which there is a higher probability of preventing harm to a much greater number by focusing elsewhere, or it may not be possible to have much confidence in knowing where the highest probability of preventing harm to the greatest number lies. It is also important to safeguard against any perceived or real reversal of worthy and unworthy victims. If one carries out research which focuses on the terrorism of official enemies such as al-Qaeda, Hamas and so on without 'balancing' it with material on the terrorism of their opponents, there will be no accusation of one-sidedness or singling out. However, if one focuses research on Northern state and state-sponsored terrorism, that accusation will be made. A rebuttal 
can rest on the arguments set out in this section of this paper and on ensuring that the definition, measurement and ethical criteria for evaluation of terrorism are applied in a consistent way. Beyond that, and especially at this early stage of the development of critical terrorism studies, it might be more prudent to decide that researching Northern terrorism can be made more politically feasible by simultaneously researching the terrorism of official enemies. This is not required in scholarly terms - research focused on particular actors is legitimate, and research on Northern and Northernsponsored actors is required to bring more balance to the field as a whole.

\section{Pay attention to the gorilla on the basketball court - state terrorism, including that of Northern states}

In a well known experiment, subjects were asked to watch a video of six people, three in white T-shirts and three in black T-shirts, playing basketball. The subjects were also asked to count the number of passes between the players wearing white T-shirts. In the 25-second video, a person in a gorilla suit walks into the middle of the scene, faces the camera and beats their chest and walks off. More than half of the subjects did not notice the gorilla (Simons, Chabris 1999 and watch the video via Viscog 1999). In this article, the gorilla on the basketball court is state terrorism, and least visible of all is Northern state terrorism due to a combination of power, ideology and path dependency. Mainstream terrorism studies, as Richard Jackson (2008) and Blakeley (2008) among others point out, pays relatively little attention to state terrorism and in particular almost entirely ignores Northern use and sponsorship of terrorism. This is so even though the concept of terrorism has its origins in state practice (the French revolution, World War Two terror bombings, the nuclear balance of terror), terrorism is an instrument that can be employed by different types of actor and it fits within the broad parameters of the definitions of terrorism often used by mainstream terrorism studies. As mentioned above, defining terrorism as actual or threatened use of violence against civilians with the aim of creating fear among other civilians as a means of achieving political goals is fairly uncontroversial. While definitions vary, this one or ones similar to it cover most of what is usually meant by terrorism, and Northern states have a long record of involvement in such practices.

Post-1945, this involvement can be traced from Indonesia, South-East Asia and Latin America in the past to governments in countries such as Colombia, Turkey and Israel today. Mainstream terrorism studies scholars have paid little attention to 
these cases (cf. critical scholars such as Chomsky, Herman 1979, George 1991, Stokes 2005, 2006, Blakeley 2007, in progress, Rejali 2007). To illustrate, the Phoenix programme established by the Central Intelligence Agency (CIA) in Vietnam in 1967 was summarised by Douglas Valentine ([1990] 2000, p. 13) as follows:

Phoenix [... was a] concerted effort to 'neutralize' the Vietcong infrastructure (VCI). The euphemism 'neutralize' meant to kill, capture, or make to defect. The word 'infrastructure' refers to those civilians suspected of supporting North Vietnamese and Vietcong soldiers ... Central to Phoenix is the fact that it targeted civilians, not soldiers ... [D]ue process was totally nonexistent. South Vietnamese civilians whose names appeared on blacklists could be kidnapped, tortured, detained for two years without trial, or even murdered, simply on the word of an anonymous informer. At its height Phoenix managers imposed quotas of eighteen hundred neutralizations per month ... VCI members were brutally murdered along with their families or neighbors as a means of terrorizing the neighboring population into a state of submission.

The scale and geographical spread of the violence directed by Northern states and their allies at civilians in order to bend societies to their will has dropped off dramatically since the Cold War peaks of Korea, Indonesia, Vietnam and then Central America (Blakeley in progress). It also never reached the levels in absolute numbers attained by Hitler, Stalin and Mao. Nevertheless, its history needs to be written and brought into the normal agenda of terrorism studies because states, including Northern ones, will do these things if they think they can get away with it, and the ultimate form of getting away with it is for it never to be known, or for it to be known at one point but forgotten. Phoenix-type themes have persisted in US foreign policy in particular with the aid of numerous other states through Central America in the 1980s to the current policies of mass incarceration without due process in Iraq and extraordinary rendition. The question that arises is how one might study the policies that produce those victims.

Many but certainly not all within mainstream terrorism studies argue that only non-state actors can be terrorists, either because of the supposed legitimacy of state violence or because what states do is somehow different in kind. Both of these 
arguments are weak - the legitimacy of state violence against civilians is a matter of dispute and the tactics they employ are often the same as those of non-state terrorists. While the arguments attempting to establish an essential difference between state terrorism and non-state terrorism are weak, at least this is an improvement on writing as if treating terrorism as a solely non-state phenomenon is commonsensical and undisputed, a staple of much of mainstream terrorism studies. Perhaps the most important difference of emphasis between state and non-state terrorism can be (but is not always) the fact that the former can involve a higher number of civilian deaths and more widespread and deeper fear among the civilian population. This is ironic, as it would suggest the need for more focus on state terrorism, not less.

The central point remains that figures within mainstream terrorism studies are of the view that state terrorism exists and that Northern states have used and sponsored terrorism (as noted in Blakeley 2008, Horgan, Boyle 2008, Jackson 2008). In their defence of mainstream terrorism studies, John Horgan and Michael Boyle (2008) point out that Paul Wilkinson has stated that:

It is also important to recognize that Western democracies have often been guilty of backing regimes and groups which have been involved in committing terrorist attacks on the civilian population. The most notable example is the role of the U.S. government during the Cold War in funding and assisting clients in Latin America during the Cold War, for example, the Somoza regime in Nicaragua and the military dictatorship in Guatemala.

That recognition, welcome as it is, has not resulted in substantial research within mainstream terrorism studies of this phenomenon as terrorism. Furthermore, it is presented as backing for regimes and groups that use terrorism without in-depth consideration of the possibility that the US actively encouraged that terrorism or the implication that US leaders such as Ronald Reagan should have faced an international criminal tribunal for doing so in the same way that Slobodan Milosevic has done for his role in Bosnia. Even more pertinently, such analysis is needed of current US involvement in places such as Colombia (Stokes 2005, 2006). Critical terrorism studies can argue that it is filling a gap in the literature of which mainstream terrorism studies accepts the existence but refuses to fill. It follows that a central task for critical terrorism studies is an empirical one, producing extensive case studies based 
on primary sources. Almost certainly a substantial amount of the recording of eye witness testimony and exploration of written and visual archives will already have been carried out by human rights organisations, lawyers, historians, ethnographers, journalists and area studies scholars. Developing scholarly knowledge of contemporary history, and engaging or encouraging contemporary historical research where there is insufficient, is a primary task for critical terrorism studies. In this process, interdisciplinary research should not be fetishised. Combining disciplines will be necessary to answer particular questions, but large numbers of contemporary historical studies and theoretically-informed political analyses will be vital to providing a firm base for critical terrorism studies.

Will anyone attempting to produce such studies struggle to have them published in leading journals and by leading publishers for political reasons? Herman and Chomsky concluded in 1988 that this problem existed:

If one chooses to denounce Qaddafi, or the Sandinistas, or the PLO, or the Soviet Union, no credible evidence is required. The same is true if one repeats conventional doctrines about our own society and its behavior - say, that the U.S. government is dedicated to our traditional noble commitment to democracy and human rights. But a critical analysis of American institutions, the way they function domestically and their international operations, must meet far higher standards; in fact, standards are often imposed that can barely be met in the natural sciences. One has to work hard, to produce evidence that is credible, to construct serious arguments, to present extensive documentation - all tasks that are superfluous as long as one remains within the presuppositional framework of the doctrinal consensus (Herman, Chomsky [1988] 2002, p. 305).

Whether or not the situation now is better is hard to measure. While there is high quality work within mainstream terrorism studies, Horgan and Boyle (2008) observe that: 'A truly exceptional volume of rubbish - often condemnatory and analytically thin books, often without any historical or theoretical grounding - followed the drama surrounding terrorism since 9/11.' In addition, it is still hard to imagine an article being published on US or Israeli state terrorism in a journal like American Political Science Review. However, critical and activist spaces for politics scholarship have 
developed, with the publication of some critical articles on terrorism in mainstream journals (e.g. Stokes 2006, Blakeley 2007) and with the launch of Critical Studies on Terrorism. Nevertheless, there is a long way to go, and an important step forward will have been taken when there are no more taboo cases.

\section{Address taboo cases - such as possible Israeli state terrorism}

No cases of possible state or non-state terrorism should be off-limits as objects of analysis. For example, mapping Northern state terrorism should include assessment of Israeli actions. It is plausible that Israel engages in actual or threatened use of violence against civilians with the primary or secondary aim of creating fear among a wider civilian population as a means of achieving political goals. In his contribution to how we might think about terrorism, Booth (2008) writes: 'Believe that blasphemy is our business'. There can be no bigger blasphemy in terrorism studies than uttering the phrase 'Israeli state terrorism' with any suggestion that there is such a thing. This is something which mainstream terrorism studies will not touch with a barge pole and which those within critical terrorism studies are liable to feel anxious about discussing. A search on Google Scholar for 'Israeli state terror' produces a mere 21 hits, 'Israeli state terrorism' 60 hits and 'Israeli terrorism' 203 hits (many of these actually referring to 'anti-Israeli terrorism') compared with 1,160 for 'Palestinian terrorism'. Searching Google produces 37,400 hits for 'Israeli terror' (1,170 referring to 'anti-Israeli terror'), 4,700 for 'Israeli state terrorism', 11,400 for 'Israeli state terrorism' and 133,000 for 'Palestinian terrorism'. If critical terrorism studies is to consider this question, it needs to do so with a great deal of care because it is an extremely politically charged subject. Criticising Israeli state policies, and especially using the label 'terrorism' to describe some of them, is likely to be equated by some as anti-Israeli and even anti-Semitic (for a rebuttal, see Butler 2004, ch. 4). Such attacks are more likely to come from private organisations and journalists than from the Israeli state itself (as discussed in Beinin 2006, Brand 2007). Richard Jackson set out in an email some initial thoughts on how various Israeli actions could be defined as terrorism using a mainstream definition of the concept. This was given to students in a class at Aberystwyth University to discuss and one of them passed it on to journalist Melanie Phillips. In turn, Phillips reproduced it in her Spectator blog and attacked terrorism studies at Aberystwyth. She also wrote to Noel Lloyd, ViceChancellor of Aberystwyth University, asserting that Jackson's material indicated his 
'apparent animus against Israel and his tendentious recycling of hateful propaganda, taken from either Arabs or their left-wing Israeli sympathisers, as facts' (Phillips 2007).

How serious a risk is one taking in raising the question of Israeli state terrorism? On the one hand, the Vice-Chancellor stood by Jackson and terrorism studies at Aberystwyth. More generally, getting involved in current Middle East politics at any level is liable to result in some fairly heated attacks which scholars can learn to take in their stride, and those with permanent academic posts are almost certain to retain them (Betts 2007). The fact that there are already some books and articles on this subject (how scholarly they are would require closer examination) shows that this is not an entirely untrodden path even if it has not managed to make a significant dent in terrorism studies. For some in peace studies, hostility to and external scrutiny of the field in the renewed Cold War of the early to mid 1980s was on balance good for the discipline in requiring scholarly standards to be exceptionally high (Rogers 2007, p. 44). Career prospects may even be enhanced by the raised profile that comes with controversy, and one is especially likely to come to this view if one sees US and UK academia as being predominantly liberal and left wing, with right wing views in a minority (Horowitz 2006, Betts 2007, p. 402). However, it could turn out badly. Mud could stick, promotion and funding prospects could be damaged and those who have not yet secured a permanent academic post could be unwilling to put being appointed to one at risk. Such concerns are not merely about academics being too thin-skinned about being challenged. It is intimidation, it threatens academic freedom and beyond that may blunt challenges to acts that would fall within definitions of terrorism used widely. The largest cost would fall on those who do or would like to engage in fieldwork in this area. Labelling any Israeli actions as terrorist could spell the end of any access one might seek to Israel or the occupied territories. This prospect alone will be enough to make most of those who wish to engage directly with the Israeli state prefer to avoid the label. Even if one is not engaged in such fieldwork, antagonising the Israeli lobby could produce difficulties for access to and academic research in the United States, where the Israeli lobby is powerful (Mearsheimer, Walt 2007).

Operating according to scrupulously high scholarly standards, aside from being the only right and proper way to proceed anyway, would be an indispensable defence in the politics of putting Israel's policies on the agenda. In addition, Booth's 
recommendations to "Always appreciate that terrorism is a powerful word, so use it with caution', 'See terrorism as a strategy, a human choice', 'Attempt to recognise the human behind the label' and 'Abolish the discourse of evil' would be of further value. Organising and gaining the backing of and protection from senior scholars would also be politically prudent. However, I doubt that all of this would be sufficient to ensure that uttering the blasphemy 'Israeli state terrorism' will not produce any of the potential costs indicated above. For many of those committed to the Israeli cause, Israel is in a desperate fight for survival against the worldwide forces of antiSemitism, and any criticism of Israel's actions must be shut down in order to prevent the first step on the slippery slope to the destruction of the state of Israel and another Holocaust. Using a label which delegitimises actions that are assumed by them to be necessary for Israel's survival will be seen as inherently biased. From this perspective, an even-handed application of a definition of terrorism to Israeli and Palestinian actions will be seen as anti-Semitic in intent or in its implications as a propaganda weapon for those who are determined to destroy Israel. Hence, if you are going to consider labelling any Israeli action terrorism, even in the context of a scrupulously careful comparison with Palestinian or Islamic terrorism, it would be politically naïve to assume that the reaction will not get dirty. Considering what Israel does on a daily basis on the ground with little interest in due process or legality, expect pleas of academic freedom and scholarly standards to receive short shrift. The fact that this topic is so fraught suggests that putting hitherto taboo cases on the agenda of terrorism studies is insufficient. There needs to be a simultaneous effort to move beyond the category of terrorism.

\section{Move beyond the category of terrorism as part of challenging all political violence, including that of the North}

Terrorism is a delegitimising concept, and delegitimising an act can translate - or be translated by others - into delegitimising an actor. The delegitimation approach to Israel's policies is evidenced in other ways, such as the framing of its policies in terms of 'ethnic cleansing' (Pappe 2007), 'apartheid' (Carter 2007, Pappe 2008) or even 'evil' (Pappe forthcoming 2008). The most useless word of all, though it is difficult to avoid, is the noun 'terrorist' due to its reductionist, essentialising character. There is always more to anyone and any group that engages in terrorism, and it may be that their use of terrorism is secondary or temporary. Delegitimation by application of 
terms such as terrorism may turn out to be a useful political practice - naming and shaming to increase the political cost of terrorism. An alternative political practice would be to hold it up as a mirror to those who apply it to their opponents. This would involve arguing the following: 'If you label those actions of your opponent as terrorism then the following actions of yours are also terrorism. So let's drop the label.' When people stop calling each other terrorists, the chances are that they are ready to negotiate seriously.

Moving beyond the category of terrorism is necessary because the label can obstruct understanding (meaning comprehension and empathy as opposed to sympathy). Googling the phrase "I am a terrorist" produces 57,300 hits and diverse meanings and contexts. Still, generally speaking, people who are in favour of acts that definitely satisfy part of and possibly satisfy all of the definition of terrorism used in this article rarely categorise those acts as terrorism themselves. The label frequently steers the discussion towards notions of evil and abnormal psychology, when the calculations and feelings involved are more common than such notions suggest. The International Committee of the Red Cross (ICRC) (1999b) carried out important research in 1999 across 17 countries worldwide into what publics think of war and in particular restraints on war. One of the cases explored in depth was Israel and the occupied and autonomous territories (ICRC 1999a): restraints on war in relation to civilians were weaker in this case than all the others studied by the ICRC. $36 \%$ of Israelis and $9 \%$ of Palestinians thought that everything is allowed in war. $7 \%$ of Israelis and $16 \%$ of Palestinians thought that it is acceptable to attack civilians as well as combatants. $22 \%$ of Israelis and $31 \%$ of Palestinians thought that selectively attacking civilians is acceptable if the other side is doing it. There were also considerable amounts of support for attacking civilians who voluntarily give food and shelter to the enemy (38\% of Israelis, $40 \%$ of Palestinians) or voluntarily give information to the enemy ( $60 \%$ of Israelis and $71 \%$ of Palestinians) and for setting off explosives in populated areas (12\% of Israelis and $17 \%$ of Palestinians).

These and many other examples of views expressed by respondents could be but are not necessarily in the category of support for terrorism in that the motive could be to achieve political goals other than through civilian fear. In answer to why soldiers and fighters (hence implying both sides) attack civilians, in descending order of priority Israelis said those who do so are committed to their cause (33\%), lose all sense during war $(28 \%)$, hate the other side $(25 \%)$, are determined to win at any cost 
(22\%), know the other side is doing the same thing (22\%), are told to do so (14\%), are scared $(12 \%)$, are too young to make judgments $(10 \%)$, don't care about the laws (4\%) and don't know the laws (3\%), with 9\% saying they didn't know or refusing to answer. Palestinians said it was because those involved hate the other side (41\%), are determined to win at any cost $(30 \%)$, are told to do so $(26 \%)$, know the other side are doing the same thing (24\%), lose all sense during war (19\%), don't care about the laws $(16 \%)$, are committed to their cause $(14 \%)$, are scared $(11 \%)$, don't know the laws $(7 \%)$ and are too young to make judgments (2\%), with 3\% saying they didn't know or refusing to answer. Hence the main reasons given are quite similar though with different weightings. They involve a mix of the instrumental (commitment and winning), the emotional (hatred) and the reactive (reciprocity) which could combine the first two. These main reasons could all involve seeking to achieve political goals through civilian fear, or they could be distinct from it: the ICRC study does not provide the data that would allow this question to be resolved. It would also have been much more revealing if the polling had asked separately why people thought their own group attacked civilians and why the other side did so to see if the results were different, with the other group's attacks on civilians viewed more negatively in their motivations. I have used the phrase 'own group' advisedly here, as the extent to which Israelis and Palestinians see themselves as separate and homogenous groups is another matter, and one that is possibly crucial to longer term resolution of the conflict.

The Israeli non-governmental organisation B'Tselem does superb human rights work in the occupied territories. It characterises political violence against civilians in terms of human rights violations and rarely uses the word terrorism. It documents and campaigns against human rights abuses by all actors in the occupied territories including the Palestinian Authority but focuses its efforts principally on Israeli actions on the grounds that it is an Israeli organization and so should concentrate primarily on actions carried out ostensibly on behalf of Israelis. Its 2007 annual report details killing of Palestinians not taking part in hostilities, killing of Israelis by Palestinians, siege and collective punishment, restrictions on Palestinian movement, violence and interrogation by Israeli forces, use of human shields, arbitrary detention, settler violence, division of families, discriminatory distribution of water, settlement expansion, expulsions and human rights violations during intraPalestinian clashes (B'Tselem 2007). It does so without using the word 'terrorism' 
once about the actions of any of those involved or terms like 'apartheid', 'ethnic cleansing' or 'evil'. Such an approach is almost certainly necessary for it to have any chance of access on the ground, but there does appear to be more to it, namely, a determination to focus positively on human rights in relation to political violence by all sides.

The approach of referring to political violence rather than terrorism is often adopted within mainstream terrorism studies. However, it is still fundamentally a delegitimising move for those whose actions are so described if that is contrasted with force or war by actors which the analyst sees as legitimate. Mainstream terrorism studies contains criticisms of Northern political violence, but mainly in terms of it being mistaken or counter-productive and much less in terms of it being illegal or illegitimate. US use of torture and rendition since 9/11 have produced more criticism of US practices on grounds of legitimacy and legality in mainstream terrorism studies than there has ever been. Nevertheless, the overall observation still applies, and political violence is still generally what 'they' do and force and war what 'we' do. The legitimacy or lack of it of actions should be arrived at separately, not smuggled in via labelling of actions, and whether the label war, political violence or force is used, the same label should be applied consistently to the same kind of action. Expressing the view that there could be any circumstances in which armed opposition to Northern state power may be legitimate - including armed opposition supported by the majority of the population against an illegal foreign occupation - is very risky in the fevered atmosphere of permanent emergency. Surveillance, harassment, prosecution for incitement and a prison sentence are a prospect that should not be discounted in the US, UK and beyond never mind Israel. All armed opposition to Northern power or even discussion of it, is being pushed into the delegitimising and criminalizing category of terrorism (Duffield 2007, p. 226). Understanding how this is the case brings us full circle back to a historical materialist analysis of the global North's domination of the global South. 9/11 intensified and accelerated this process but did not cause it - it was a consequence mainly of the end of the Cold War and hence the removal of a significant element of opposition to Western, now Northern, power. In contrast, advocacy of invasion, occupation, bombing and assassination by Northern states and their allies with scant or no regard for international law, and with many civilian casualties, is the common currency of much - though importantly, by no means all - of mainstream terrorism studies. There is significant potential for 
common cause with those in mainstream terrorism scholars who reject such policies on principle.

As terrorism and political violence are so blurred, challenging one necessarily involves a challenge to the other. This would represent yet another substantial difference in emphasis between mainstream and critical terrorism studies. For those seeking to contribute to progressive social change, principle and pragmatism both point towards a commitment to promotion of non-violence without necessarily requiring a commitment to pacifism defined as the principled rejection of political violence in all circumstances, including self-defence. These recommendations chime with Booth's (2008) arguments that 'praxis is our profession' and the struggle against terrorism is part of the struggle against all political violence. For critical terrorism studies to advance and challenge the mainstream approach, adoption of rights-based opposition to political violence informed by a historical materialist understanding of the structures and processes of world politics will contribute substantially to analysis and activism.

\section{Conclusion}

There is a pressing need for critical terrorism studies. Mainstream terrorism studies obscures the class function of terrorism, values the worthy victims of official enemies over the unworthy victims of official allies, keeps Northern state terrorism off the agenda and deploys the concept of terrorism in a way that delegitimises opposition to the power of the global North while legitimising the global North's own political violence. Critical terrorism studies should break with mainstream terrorism studies on all of these fronts. It should address how terrorism has evolved as an instrument of the power and privilege of the global North. It should treat the victims of terrorism equally on the basis of their common humanity, which means the terrorism of the global North or global South should not be treated as the only terrorism that matters. And it should use the label terrorism to hold up a mirror to those who accuse others of terrorist acts but who engage in, sponsor or are complicit in such acts themselves. Finally, it should situate its challenge to terrorism within a challenge to the use of political violence in general. In 1979, Chomsky and Herman (1979, p. ix) argued that:

The basic fact is that the United States has organized under its sponsorship and protection a neo-colonial system of client states ruled mainly by terror and 
serving the interests of a small local and foreign business and military elite. The fundamental belief, or ideological pretense, is that the United States is dedicated to furthering the cause of democracy and human rights throughout the world, though it may occasionally err in the pursuit of this objective.

28 years later, Duffield (2007, p. 226) observed:

If the outlawing of exiled regimes calling for political change has been a gift to despotic regimes, these regimes are reciprocating by providing democratic states with covert security services such as detention without trial, torture and extrajudicial murder that are otherwise illegal under their own laws.

Furthermore, as Human Rights Watch showed, these despotic regimes seek to pass themselves off as democratic (Human Rights Watch 2008, Roth 2008). Hence the argument that Northern state terrorism - use, sponsorship and complicity - is part of the class ordering of contemporary capitalism is not new. However, that argument must be taken up anew for critical terrorism studies to make a politically and intellectually worthwhile contribution. If this project is to succeed it must have an analysis of why past work of Chomsky, Herman, Alexander George (1991) and others did not remake the mainstream. It must have a strategy so that it will succeed this time, persuading and building bridges to those currently in the mainstream who are open to a new approach and agenda. It also must explore the extent to which the role of terrorism is changing and possibly even declining in importance in terms of buttressing the class relations that protect the privilege of the global North. Chomsky and Herman were writing when coercion, and especially terrorism, were uppermost in maintaining US dominance in Central America. Class rule probably rests more commonly on consent through ideological hegemony in Gramscian terms (Overbeek 2004, p. 3). This kind of research and political agenda are a far cry from the preoccupations of mainstream terrorist studies. Overall, critical terrorism studies needs to reflect on how to remake the mainstream rather than be a marginal alternative to it (Herring 2006, Gunning 2007, Lawson 2008). At a minimum this will involve generating substantial amounts of theoretical and empirical scholarly output of the highest possible standard to alter the current path dependency; engaging with non-academic activists so that scholarship and political practice are connected; taking 
the argument onto the home ground of mainstream scholarship; assessing how scholarship contributes to actually existing non-violent struggles against terrorism and political violence including that of Northern states; and measuring the worth of our scholarship by all of the above rather by the priorities of what is currently the mainstream of terrorism studies. 


\section{References}

Antipode, n.d. Antipode: a radical journal of geography [online]. Available from: http://www.blackwell-synergy.com/loi/anti [Accessed 23 April 2008].

Beinin, Joel, 2006. The new McCarthyism: policing thought about the Middle East. In: Beshara Doumani, ed. Academic freedom after September 11. New York: Zone Books, 237-266.

Betts, Richard K., 2007. Freedom, license and responsibility. International studies perspectives, 8 (4), 401-409.

Blakeley, Ruth, 2007. Bringing the state back into terrorism studies, European political science, 6 (3), 228-235.

Blakeley, Ruth, 2008. Reinventing the wheel? State terrorism, Northern democratic states, and critical terrorism studies (a response to John Horgan and Michael J. Boyle), Critical studies on terrorism, 1(2), xx-xx.

Blakeley, Ruth, in progress. State terrorism in the global South: foreign policy, neoliberalism and human rights. London: Routledge.

Booth, Ken, 2005a. Beyond critical security studies. In: Ken Booth, ed. Critical security studies and world politics, Boulder: Lynne Rienner, 259-278.

Booth, Ken, ed., 2005b. Critical security studies and world politics. Boulder: Lynne Rienner.

Booth, Ken, 2007. Theory of World Security. Cambridge: Cambridge University Press.

Booth, Ken, 2008. The human facts of terror: reflections in a cracked looking glass, Critical studies on terrorism, 1 (2), $\mathrm{xx}-\mathrm{xx}$.

Brand, Laurie, 2007. Middle East studies and academic freedom: challenges at home and abroad. International studies perspectives, 8, 384-395.

B'Tselem, 2007. Human rights in the occupied territories: 2007 annual report - draft [online]. Available at: http://www.btselem.org/Download/200712_Annual_Report_eng.pdf [Accessed 25 April 2008].

Butler, Judith, 2004. Precarious life: the powers of mourning and violence. London: Verso.

Carter, Jimmy, 2007. Palestine: peace not apartheid. New York: Simon \& Schuster. 
Chomsky, Noam, 1989. Necessary illusions: thought control in democratic societies. Boston: South End Press.

Chomsky, Noam, 2001. What is wrong with science and rationality?, in Greg Philo and David Miller (eds) Market killing. What the free market does and what social scientists can do about it. Harlow: Pearson.

Cohen, Nick, 2007. What's left? How liberals lost their way. London: Fourth Estate.

Collins, Alan, ed., 2007. Contemporary security studies. Oxford: Oxford University Press.

Duffield, Mark, 2007. Development, security and unending war. Cambridge: Polity.

Fierke, Karin, 2007. Critical approaches to international security. Cambridge: Polity.

George, Alexander, ed., 1991. Western state terrorism. Cambridge: Polity.

Gunning, Jeroen, 2007. Babies and bathwaters: reflecting on the pitfalls of critical terrorism studies. European political science, 6 (3), 236-243.

Harvey, David, 2000. The new imperialism. Oxford: Oxford University Press.

Harvey, David, 2005. A brief history of neoliberalism. Oxford: Oxford University Press.

Herring, Eric, 2006. Remaking the mainstream: the case for activist IR scholarship. Millennium: Journal of International Relations, 35 (1), 105-118.

Herring, Eric, forthcoming 2008. Neoliberalism versus peacebuilding in Iraq. In: Neil Cooper, Michael Pugh and Mandy Turner, eds. Whose peace? Critical perspectives on the political economy of peacebuilding. London: Palgrave.

Hobden, Stephen and Richard Wyn Jones, 2005. Marxist theories of international relations. In: John Baylis and Steven Smith, eds. The globalization of world politics. 3rd ed. Oxford: Oxford University Press, 225-249.

Horgan, John and Michael J. Boyle, 2008. A case against "critical terrorism studies". Critical terrorism studies, 1 (2), xx-xx.

Horowitz, David, 2006. The professors. The 101 most dangerous academics in America. Washington, DC: Regnery Publishing.

Human Rights Watch, 2008. World report: events of 2007 [online]. Available at: http://hrw.org/wr2k8/pdfs/wr2k8_web.pdf [Accessed 25 April 2008].

ICCG, n.d. International Critical Geography Group [online]. Available at: http://econgeog.misc.hit-u.ac.jp/icgg/ [Accessed 23 April 2008].

ICRC, 1999a. Country report: Israel, the occupied territories and the autonomous territories. People on war: ICRC worldwide consultation on the rules of war. 
Report by Greenberg research inc. Geneva: International Committee of the Red Cross. Available at:

http://www.icrc.org/Web/eng/siteeng0.nsf/htmlall/Greenberg_reports/\$File/isr ael.pdf [Accessed 25 April 2008].

ICRC, 1999b. The people on war report. People on war: ICRC worldwide consultation on the rules of war. Report by Greenberg research inc. Geneva: International Committee of the Red Cross. Available at: http://www.icrc.org/Web/Eng/siteeng0.nsf/htmlall/p0758/\$File/ICRC_002_07 58.PDF!Open [Accessed 25 April 2008].

Jackson, Richard, 2007. The core commitments of critical terrorism studies. European political science, 6 (3), 244-251.

Jackson, Richard, 2008. The ghosts of state terror: knowledge, politics and terrorism studies. Paper prepared for the International Studies Association annual conference, 26-29 March, 2008, San Francisco, USA.

Jessop, Bob, 2002. The future of the capitalist state. Cambridge: Polity. Jessop, Bob, 2003. Globalization and the national state [online]. Department of Sociology, University of Lancaster, 5 December. Available at: http://www.lancs.ac.uk/fass/sociology/papers/jessop-globalization-and-thenational-state.pdf [Accessed 25 April 2008].

Jessop, Bob, 2007. From micro-powers to governmentality: Foucault's work on statehood, state formation, statecraft and state power. Political geography, 26, 34-40.

Krause, Keith and Michael C. Williams, eds., 1997. Critical security studies: concepts and cases. Minneapolis, MN: University of Minnesota Press.

Krause, Keith, 1998. Critical theory and security studies: the research programme of “critical security studies". Cooperation and conflict, 33 (3), 298-333.

Lawson, George, 2008. For a public international relations. International political sociology, 2 (1), 17-37.

Mearsheimer, John J. and Stephen M. Walt, 2007. The Israel lobby and US foreign policy. London: Allen Lane.

Mutimer, David, 2007. Critical security studies: a schismatic history. In: Alan Collins, ed. Contemporary security studies. Oxford: Oxford University Press, $53-74$. 
Naspir, n.d. Network of activist scholars of politics and international relations [online. Available at: http://www.naspir.net [Accessed 5 May 2008].

Overbeek, Henk, 2004. Global governance, class, hegemony: a historical materialist perspective [online]. Working papers in political science, No. 2004/01. Available at: http://www.arccgor.nl/uploads/File/Workingpaperhenk.pdf [Accessed 23 April 2008].

Pappe, Ilan, 2007. The ethnic cleansing of Palestine, Oxford: Oneworld.

Pappe, Ilan, ed., 2008. Peoples apart: Israel, South Africa, and the apartheid question. London: I.B. Tauris.

Pappe, Ilan, forthcoming 2008. The bureaucracy of evil: the history of the Israeli occupation. Oxford: Oneworld.

Philips, Melanie, 2008. Terror in academia [online]. Melanie Philips blog, The Spectator, 5 April. Available at: http://www.spectator.co.uk/melaniephillips/612861/terror-in-academia.thtml [Accessed 23 April 2008].

Rejali, Darius, 2007. Torture and democracy. Princeton, NJ: Princeton University Press.

Rogers, Paul, David, 2007. Peace studies. In: Alan Collins, ed. Contemporary security studies. Oxford: Oxford University Press, 35-52.

Roth, Kenneth, 2008. Despots masquerading as democrats [online]. Human Rights Watch. Available at: http://hrw.org/wr2k8/introduction/introduction.pdf [Accessed 25 April 2008].

Shaw, Martin, 2001. The unfinished global revolution: intellectuals and the new politics of international relations. Review of international studies, 27 (4), 62747.

Simons, Daniel J. and Christopher F. Chabris, 1999. Gorillas in our midst: sustained inattentional blindness for dynamic events. Perception, 28 (9), 1059-1074.

Stokes, Doug, 2005. America's other war. Terrorizing Colombia. London: Zed.

Stokes, Doug, 2006. "Iron fists in iron gloves": the political economy of terrorocracy promotion. British Journal of Politics and International Relations, 8, 368-387.

Valentine, Douglas, [1990] 2000. The Phoenix program. Lincoln, NE: Authors Guild Backinprint.com.

Viscog, 1999. Opaque gorilla from Simons and Chabris [online]. Visual Cognition Lab, University of Illinois. Available at: 
http://viscog.beckman.uiuc.edu/grafs/demos/15.html [Accessed 23 April 2008].

Wyn Jones, Richard, 1999. Security, strategy, and critical theory. Boulder, CO: Lynne Rienner. 


\section{SPAIS}

\section{Working Paper Series}

WP 03-08 Eric Herring, 'Critical Terrorism Studies: An Activist Scholar Perspective'

WP 02-08 Gurchathen Sanghera, Marsha Henry and Paul Higate, 'Peacekeepers as New Men? Security and Masculinity in the United Nations Mission in Liberia'

WP 01-08 Mark Duffield, 'On the Edge of "No Man's Land”: Chronic Emergencies in Myanmar'

WP 04-07 Nieves Pérez-Solózano-Borragán and Stijn Smismans, 'The European Economic and Social Committee after Enlargement'

WP 03-07 Terrell Carver, 'Sex, Gender and Heteronormativity: Seeing "Some like it Hot" as a Hetersexual Dystopia'

WP 02-07 Eric Herring, 'Neoliberalism versus Peacebuilding in Iraq'

WP 01-07 Terrell Carver, 'Materializing the Metaphors of Global Cities:

Singapore and Silicon Valley' 
